Reprod. Nutr. Dévelop.; 1981, 21 (6 A), 919-927.

\title{
Gonadal effects of melatonin in the three-spined stickleback, Gasterosteus aculeatus L., during different seasons and photoperiods
}

par B. BORG, P. EKSTRÖM

Deportment of Zoology, University of Lund, Helgonavägen 3, S-223 62 Lund, Sweden.

Summary. Males and females of the three-spined stickleback, Gasterosteus aculeotus L., were given melatonin injections $(0.8$ or $4 \mu \mathrm{g} / \mathrm{day})$ at different seasons and under different photoperiods (8L : 16D and $16 \mathrm{~L}: 8 \mathrm{D}$ ). Long photoperiods stimulated reproduction in November and January, whereas maturation in both sexes in March/April and ovarian regression in July were only negligibly affected by light. The high dose of melatonin induced antigonadal effects in both sexes under 16L : 8D in November and January. The low melatonin dose had progonadal effects under long photoperiod in females that had been maintained for some months under winter conditions and in females during the $8 \mathrm{~L}: 16 \mathrm{D}$ regime in July.

\section{Introduction.}

The annual reproductive cycle of the three-spined stickleback is influenced by the photoperiod (van den Eeckhoudt, 1946 ; Baggerman, 1957, 1972). The photoperiodic effects are, however, strongly dependent on season and temperature (Baggerman, 1957, 1972). During the breeding season the male stickleback displays a hypertrophied kidney and usually a brilliant breeding colour. Renal hypertrophy is androgendependent (Wai and Hoar, 1963).

In teleosts, the indolamine melatonin ( $N$-acetyl-5-methoxytryptamine) has been demonstrated in the pineal organ of Oncorhynchus (Fenwick, 1970), in the retina of Platycephalus (Reed and Finnin, 1973) and Salmo (Gern, Owens and Ralph, 1978a) and in the plasma of Salmo (Gern, Owens and Ralph, 1978b). The enzyme, hydroxyindole-Omethyltransferase (HIOMT), which catalyses the final step in the synthesis of melatonin, has been demonstrated in the pineal organ and/or retina of several teleosts (Quay, 1965 ; Hafeez and Quay, 1970 ; Smith and Weber, 1976).

In Salmo the melatonin content of plasma (Gern, Owens and Ralph, 1978b) and the HIOMT activity in the pineal organ (Smith and Weber, 1976) are considerably higher at night than during the day.

As in other investigated teleosts (e.g. Owman and Rüdeberg, 1970), the pineal organ of the three-spined stickleback exhibits indolamine fluorescence after formal- 
dehyde treatment (van Veen et al., 1980), demonstrating the presence of 5-hydroxytryptamine (5-HT) and/or 5-hydroxytryptophan (5-HTP). 5-HT and 5-HTP can serve as precursors to melatonin, and their presence indicate its possible synthesis.

The administration of melatonin has in many cases been found to influence photoperiodic effects on reproduction in vertebrates. In teleosts, melatonin has antigonadal effects when reproduction would otherwise be stimulated by long photoperiods (Fenwick, 1970 ; Urasaki, 1972 ; de Vlaming, Sage and Charlton, 1974a, b; Sundararaj and Keshavanath, 1976 ; Saxena and Anand, 1977).

The object of our study was to elucidate a possible involvement of melatonin in the annual reproductive cycle of the stickleback.

\section{Material and methods.}

Adult three-spined sticklebacks (Gasterosteus aculeatus L.) were caught in Öresund or in the southern Baltic Sea. Each experimental group (containing in itially 20 males and females each, except in experiment 3 ) was placed in an aquarium containing $45 \mathrm{I}$ of artificial brackish water with a salinity of approx. $1.1 \mathrm{p} .100$. The water was aerated and, in most experiments, filtered. The aquaria contained gravel, but no plants. The fish were fed daily with ground frozen fish meat or frozen opossum shrimps (Neomysis). All the experiments were carried out at a temperature of $20 \pm 2{ }^{\circ} \mathrm{C}$. Philips TL $40 \mathrm{~W} / 55$ fluorescent lamps served as a light source. The light intensity at the water surface was approx. 250 lux in experiments 3, 4, and 6 and approx. 1300 lux in experiments 1, 2, 5, and 7. Mortality was low in all experiments, averaging 1.6 p. 100.

Dates of capture and experiments, photoperiods and melatonin-doses in the different experiments are shown in table 1 . The fish were injected with $0.05 \mathrm{ml}$ saline or 0.8 or $4 \mathrm{\mu g}$ melatonin in $0.05 \mathrm{ml}$ saline. The melatonin was first dissolved in a few drops of ethanol, which was diluted with saline. A small amount of ethanol was also added to

TABLE 1

Experimental treatments

\begin{tabular}{|c|c|c|c|c|}
\hline & Capture & Exp.-start & Light : Dark, hrs & Melatonin $\mu \mathrm{g} /$ day \\
\hline $\begin{array}{l}\text { Experiment } 1 \ldots \\
\text { Experiment } 2 \ldots \\
\text { Experiment } 3 \ldots \\
\text { Experiment } 4 \ldots \\
\text { Experiment } 5 \ldots \\
\text { Experiment } 6 \ldots \\
\text { Experiment } 7 \ldots\end{array}$ & $\begin{array}{r}\text { Nov.-78 }\left({ }^{1}\right) \\
\text { Oct., Nov.-78 }\left({ }^{1}\right) \\
\text { Aug.-77 }\left({ }^{3}\right) \\
\text { Jan.-March-78 }\left({ }^{1}\right) \\
23 / 3-79\left({ }^{1}\right) \\
28 / 4-78\left({ }^{6}\right) \\
\text { Apr.-79 }\left(^{6}\right)\end{array}$ & $\begin{array}{l}12 / 11-78 \\
6 / 1-79 \\
25 / 5-78\left(^{4}\right) \\
25 / 5-78 \\
28 / 3-79 \\
29 / 6-78\left(^{4}\right) \\
26 / 6-79\end{array}$ & $\begin{array}{l}8: 16 ; 16: 8 \\
8: 16 ; 16: 8 \\
15.5: 8.5 \\
15.5: 8.5 \\
8: 16 ; 16: 8 \\
15.5: 8.5 \\
8: 16 ; 16: 8\end{array}$ & $\begin{array}{l}0\left(^{2}\right), 0.8 \text { or } 4 \\
0,0.8 \text { or } 4 \\
0 \text { or } 0.8\left(^{5}\right) \\
0 \text { or } 0.8 \\
0 \text { or } 0.8 \\
0,0.8 \text { or } 4 \\
0,0.8 \text { or } 4\end{array}$ \\
\hline
\end{tabular}

$\left({ }^{1}\right)$ Kept under winter conditions $\left(8^{\circ} \mathrm{C}\right.$, LD $\left.8: 16\right)$ until start of the experiment.

(2) 1 fish accidentally transferred from the 16L:8D $0 \mu \mathrm{g}$ to the $16 \mathrm{~L}: 8 \mathrm{D} 0.8 \mu \mathrm{g}$ group at the beginning of the experiment.

$\left({ }^{3}\right)$ Breeding in Dec.-Feb., winter conditions from March.

$\left({ }^{4}\right)$ No initial controls.

(5) 12 or 13 fish in each group.

$\left.{ }^{6}\right)$ Kept in running tapwater (ca. $14^{\circ} \mathrm{C}$ ) and natural photoperiod until start of the experiment. 
the control saline. The injections were given daily for 21 days, starting at the day after the fish had been put in the experimental tanks and ending the day before dissection. Each day, the fish were caught, injected intraperitoneally (needle diameter $0.4 \mathrm{~mm}$ ) and put back in the aquarium where they immediately swam as usual. There was little problem with fluid flowing out of the wound. All injections were given within $1 \mathrm{~h}$ after the onset of the light phase.

The sticklebacks were not fed on the day of dissection. The fish were weighed alive to the nearest $0.01 \mathrm{~g}$. After decapitation the gonads were excised and weighed to the nearest $0.1 \mathrm{mg}$. Both gonads were weighed and treated histologically together. Some specimens that were infected with Schizocephalus-type tapeworms were rejected.

Gonads and male trunk kidneys were fixed in Bouin-Hollande fluid or (experiment 1) in Ammerman's fluid (Ammerman, 1950). After embedding in Paraplast or Histowax, ovaries were sectioned at $7 \mu \mathrm{m}$ and testes and kidneys at $4 \mu \mathrm{m}$. The testes and some of the ovaries were serially sectioned. The sections were stained with the tetrachrome combination Chromotrope 2R, Orange G, Light green and Weigert's haematoxylin.

All histological observations were made blindly. At least six sections of the ovaries or testes from each specimen were studied. Some sections from the same fish were observed independently. Observations of serially-sectioned ovaries revealed a rather uniform histology within a specimen.

In the histological evaluation of the ovaries, the descriptions and photographs of the ovary of the brook stickleback, Eucalia (Culaea), by Braekevelt and McMillan (1967) were used. The oocytes were arbitrarily divided into the following developmental classes with the approximately corresponding classes of Braekevelt and McMillan (1967) given in parentheses: A. Non-yolky oocytes (3 and lower) ; B. Some deposition of primary yolk peripherally (early 4) ; C. Heavy accumulation of primary yolk, which, however, does not fill the entire cytoplasm (late 4); D. Primary yolk fills the entire cytoplasm (5) ; E. Primary yolk fills the entire cytoplasm, later stage (late 5) ; F. Beginning of deposition of secondary yolk peripherally $(6) ; G$. Secondary yolk fills the entire egg, final maturation (7).

Apart from the oocyte maturation, the presence of atretic eggs was also noted. The ovaries in experiments $1-5$ were divided into eight classes: ovaries with a large number of atretic eggs, with no regard to the maturation of non-atretic eggs, formed the first class (Atr.). Ovaries not containing large numbers of atretic eggs were divided into seven classes (A-G) after the status of the most mature healthy oocytes present in appreciable numbers. It must be noted, however, that all ovaries, except the most immature, contained eggs in different stages of development.

The ovaries of experiments 6 and 7, which almost all contained large numbers of atretic eggs, were classified after the most mature non-atretic eggs present (A-G). Further, the presence of large atretic eggs was noted.

The festes were divided into 3 classes : 1 . Spermatozoa dominate ; earlier stages completely or almost lacking ; 2 . Intermediate ; 3 . Large numbers of spermatogonia and/or spermatocytes present in many lobules, usually together with spermatozoa.

Ten ocular micrometer measu rements (five each from two well-separated sections) were taken of the epithelium height of the kidney $(\mathrm{KEH})$ secondary proximal tubules of each male. 
Body weights, $\mathrm{KEH}$, and gonosomatic indexes were compared by using the nonparametric Mann-Whitney U-test, as the values were not normally distributed. For the same reason standard deviations are not given, since this measurement is only meaningful if the samples are normally distributed and/or large. The maturation status of the ovaries was also compared with the Mann-Whitney U-test after ranking the classes in the following order: Atr., A, B, C, D, E, F, G.

\section{Results.}

The results are presented in tables 2 (females) and 3 (males). Spermatogenesis and testicular weights were little influenced by light regime and melatonin.

Late autumn.

Experiment 1. The long pholoperiod (16L:8D) was stimulatory. In saline and low-dose melatonin-injected males the kidney epithelium height (KEH) was higher under 16L: $8 \mathrm{D}$ than under $8 \mathrm{~L}: 16 \mathrm{D}$. There were fewer ovaries with a large number of atretic eggs and also a more advanced oocyte maturation under 16L : 8D than under $8 \mathrm{~L}: 16 \mathrm{D}(0$ and $0.8 \mu \mathrm{g}$ mel.). The low melatonin dose had no effects on reproduction. The high melatonin dose had an antigonadal effect, viz. decreased the KEH. Under 16L : 8D the high dose had an antigonadal effect on the ovarian histology.

\section{Winter.}

Experiment 2. 16L : 8D was stimulatory, having virtually the same effects as in experiment 1 when compared with $8 \mathrm{~L}: 16 \mathrm{D}$. Similarily as in experiment 1 , the high dose of melatonin had anti-gonadal effects on ovarian histology and KEH in 16L :8D (only the latter effect was significant). The low dose of melatonin had no effect on male reproduction, but a tendency to increased maturation in the female compared with the saline injected fish was found in $16 \mathrm{~L}: 8 \mathrm{D}$.

Off-seasonal breeding group.

Experiment 3. These fish were put to breeding in Dec.-Feb. and in winter conditions for a few months prior to the experiment. Low dose melatonin injections increased ovarian maturation, although the development was little advanced in both groups.

\section{Delayed spring group.}

Experiment 4. The start of breeding was delayed by low temperature treatment. Melatonin had an insignificant stimulatory effect on the ovaries.

Late spring.

Experiment 5. Almost all the specimens reached full maturity regardless of photoperiod and melatonin administration.

End of breeding season.

Experiments 6 and 7. In experiment 6 melatonin decreased gonadal weights in 
TABLE 2

Effects of melatonin on ovaries in different seasons and under different photoperiods

\begin{tabular}{|c|c|c|c|c|c|c|c|c|c|c|c|c|c|c|}
\hline \multirow{2}{*}{\multicolumn{3}{|c|}{ Experiment }} & \multirow{3}{*}{$\frac{n}{9}$} & \multirow{3}{*}{$\frac{\mathrm{BW}, \mathrm{g} \overline{\mathrm{x}}}{1.66}$} & \multirow{3}{*}{$\frac{G S I \bar{x}}{2.51}$} & \multirow{3}{*}{$\frac{\text { Arr. }}{-}$} & \multicolumn{7}{|c|}{ Ovarion developmental class (frequency) } & \multirow{3}{*}{ L. Atr./n } \\
\hline & & & & & & & $A$ & B & $c$ & D & $\mathbf{E}$ & $\mathbf{F}$ & G & \\
\hline 1 & \multicolumn{2}{|c|}{ Initial controls } & & & & & - & 1 & 6 & 1 & 1 & - & - & \\
\hline & $8 \mathrm{BL}: 16 \mathrm{D}$ & $\begin{array}{l}0 \mu g \\
0.8 \mu g \\
4 \mu g\end{array}$ & $\begin{array}{r}10 \\
12 \\
7\end{array}$ & $\begin{array}{l}1.16 \\
1.53 \\
1.18\end{array}$ & $\begin{array}{l}3.42 \\
3.13 \\
3.70\end{array}$ & $\begin{array}{l}5 \\
4 \\
4\end{array}$ & - & - & $\begin{array}{l}3 \\
3 \\
2\end{array}$ & $\begin{array}{l}1 \\
4 \\
1\end{array}$ & 1 & E & $\begin{array}{l}-\left({ }^{(B)}\right) \\
-\left({ }^{B}\right) \\
-\end{array}$ & \\
\hline & $16 \mathrm{~L}: 8 \mathrm{D}$ & $\begin{array}{l}0 \mu \mathrm{g} \\
0.8 \mu \mathrm{g} \\
4 \mu \mathrm{g}\end{array}$ & $\begin{array}{l}10 \\
11 \\
17\end{array}$ & $\begin{array}{l}1.39 \\
1.64 \\
1.45\end{array}$ & $\begin{array}{l}3.80 \\
4.22 \\
3.54\end{array}$ & $\overline{-}$ & $\bar{z}$ & $\begin{array}{l}\overline{1} \\
3\end{array}$ & $\begin{array}{l}3 \\
2 \\
4\end{array}$ & $\begin{array}{l}4 \\
2 \\
5\end{array}$ & $\begin{array}{l}-4 \\
-\end{array}$ & $\begin{array}{l}2 \\
1 \\
1\end{array}$ & $\begin{array}{r}1{ }^{\left({ }^{B}\right)},\left({ }^{a}\right) \\
1{ }^{(B)},\left({ }^{(C)}\right. \\
-\left({ }^{(}\right),\left({ }^{(}\right)\end{array}$ & \\
\hline \multirow[t]{3}{*}{2} & \multicolumn{2}{|l|}{ Initial controls } & 15 & 1.21 & 3.67 & - & - & - & 4 & 1 & 8 & - & - & \\
\hline & $8 \mathrm{~L}: 16 \mathrm{D}$ & $\begin{array}{l}0 \mu g \\
0.8 \mu g \\
4 \mu g\end{array}$ & $\begin{array}{l}12 \\
14 \\
12\end{array}$ & $\begin{array}{l}1.24 \\
1.30 \\
1.27\end{array}$ & $\begin{array}{l}3.71 \\
4.10 \\
4.22\end{array}$ & $\begin{array}{l}5 \\
7 \\
7\end{array}$ & $\bar{z}$ & - & $\begin{array}{r}\overline{2} \\
2\end{array}$ & $\begin{array}{l}2 \\
1 \\
2\end{array}$ & $\begin{array}{r}5 \\
2 \\
-\end{array}$ & $\overline{2}$ & $\overline{-}\left({ }^{(8)}\right)$ & \\
\hline & $16 \mathrm{~L}: 8 \mathrm{D}$ & $\begin{array}{l}0 \mu g \\
0.8 \mu g \\
4 \mu g\end{array}$ & $\begin{array}{r}9 \\
10 \\
13\end{array}$ & $\begin{array}{l}1.36 \\
1.37 \\
1.49\end{array}$ & $\begin{array}{r}4.44 \\
5.48 \\
4.97\end{array}$ & $\overline{\overline{5}}$ & $\bar{z}$ & $\frac{1}{-}$ & $\begin{array}{l}2 \\
1 \\
1\end{array}$ & $\begin{array}{l}1 \\
1 \\
1\end{array}$ & $\begin{array}{l}3 \\
4 \\
4\end{array}$ & $\begin{array}{l}-4 \\
2\end{array}$ & ${ }^{1}-\left({ }^{\mathrm{B}}\right)$ & \\
\hline 3 & $15.5 \mathrm{~L}: 8.5 \mathrm{D}$ & $\begin{array}{l}0 \mu \mathrm{g} \\
0.8 \mu \mathrm{g}\end{array}$ & $\begin{array}{l}8 \\
8\end{array}$ & $\begin{array}{l}1.11 \\
1.13\end{array}$ & $\begin{array}{l}1.42\left(^{(a)}\right. \\
5.37\left(^{(8)}\right.\end{array}$ & $\overline{-}$ & $\begin{array}{l}7 \\
3\end{array}$ & $\begin{array}{l}1 \\
3\end{array}$ & $\overline{1}$ & - & 二 & $\overline{-}$ & - & \\
\hline \multirow[t]{2}{*}{4} & \multicolumn{2}{|c|}{ Inifial controls } & 13 & 1.32 & 7.66 & 1 & - & 一 & 1 & - & 2 & 3 & 5 & \\
\hline & $15.5 \mathrm{~L}: 8.5 \mathrm{D}$ & $\begin{array}{l}0 \mu \mathrm{g} \\
0.8 \mu \mathrm{g}\end{array}$ & $\begin{array}{l}12 \\
11\end{array}$ & $\begin{array}{l}1.19 \\
1.36\end{array}$ & $\begin{array}{r}9.09 \\
13.86\end{array}$ & 1 & - & - & $\begin{array}{l}1 \\
1\end{array}$ & $\overline{-}$ & - & $\frac{3}{-}$ & $\begin{array}{r}6 \\
10\end{array}$ & \\
\hline \multirow[t]{3}{*}{5} & \multicolumn{2}{|c|}{ Initial controls } & 10 & 1.09 & 6.42 & - & - & - & - & 1 & 3 & 5 & 1 & \\
\hline & $8 \mathrm{~L}: 16 \mathrm{D}$ & $\begin{array}{l}0 \mu g \\
0.8 \mu g\end{array}$ & $\begin{array}{r}9 \\
10\end{array}$ & $\begin{array}{l}1.47 \\
1.26\end{array}$ & $\begin{array}{l}15.31 \\
12.60\end{array}$ & $\begin{array}{l}2 \\
3\end{array}$ & $\overline{-}$ & $\overline{-}$ & $\overline{-}$ & $\overline{-}$ & $\overline{-}$ & $\overline{-}$ & $\begin{array}{l}7 \\
7\end{array}$ & \\
\hline & $16 \mathrm{~L}: 8 \mathrm{D}$ & $\begin{array}{l}0 \mu \mathrm{g} \\
0.8 \mu \mathrm{g}\end{array}$ & $\begin{array}{l}10 \\
11\end{array}$ & $\begin{array}{l}1.28 \\
1.24\end{array}$ & $\begin{array}{l}12.43 \\
12.60\end{array}$ & $\overline{1}$ & - & $\overline{-}$ & 二 & $\overline{-}$ & $\overline{-}$ & $\begin{array}{l}2 \\
2\end{array}$ & $\begin{array}{l}8 \\
8\end{array}$ & \\
\hline 6 & 15.5L : 8.5D & $\begin{array}{l}0 \mu g \\
0.8 \mu g \\
4 \mu g\end{array}$ & $\begin{array}{l}15 \\
11 \\
14\end{array}$ & $\begin{array}{l}0.83 \\
0.82 \\
0.78\end{array}$ & $\begin{array}{l}5.35\left({ }^{a}\right) \\
4.17 \\
2.81\left(^{a}\right)\end{array}$ & & $\begin{array}{l}5 \\
4 \\
5\end{array}$ & $\begin{array}{l}7 \\
6 \\
5\end{array}$ & $\begin{array}{l}1 \\
1 \\
4\end{array}$ & $\frac{1}{-}$ & - & $=$ & $\frac{1}{-}$ & $\begin{array}{l}3 / 15 \\
2 / 11 \\
1 / 14\end{array}$ \\
\hline \multirow[t]{3}{*}{7} & \multicolumn{2}{|c|}{ Initial controls } & 18 & 1.36 & 13.75 & & - & 1 & - & - & 2 & 1 & 14 & $0 / 18$ \\
\hline & $8 \mathrm{LL}: 16 \mathrm{D}$ & $\begin{array}{l}0 \mu g \\
0.8 \mu g \\
4 \mu g\end{array}$ & $\begin{array}{l}19 \\
19 \\
19\end{array}$ & $\begin{array}{l}1.18 \\
1.24 \\
1.16\end{array}$ & $\begin{array}{l}5.01\left({ }^{d}\right) \\
9.62(d),\left(d^{d}\right) \\
4.98\left({ }^{A}\right),\left(d^{(d)}\right)\end{array}$ & & $\begin{array}{l}2 \\
5 \\
6\end{array}$ & $\begin{array}{l}13 \\
11 \\
10\end{array}$ & $\begin{array}{l}3 \\
2 \\
2\end{array}$ & = & $\overline{1}$ & $\begin{array}{l}- \\
-\end{array}$ & $\begin{array}{r}1 \\
1 \\
-\end{array}$ & $\begin{array}{l}3 / 19 \\
9 / 19 \\
1 / 19\end{array}$ \\
\hline & $16 \mathrm{~L}: 8 \mathrm{D}$ & $\begin{array}{l}0 \mu g \\
0.8 \mu g \\
4 \mu g\end{array}$ & $\begin{array}{l}17 \\
20 \\
19\end{array}$ & $\begin{array}{l}1.22 \\
1.20 \\
1.13\end{array}$ & $\begin{array}{l}5.73 \\
7.12 \\
7.87\left({ }^{\wedge}\right)\end{array}$ & & $\begin{array}{l}11 \\
13 \\
12\end{array}$ & $\begin{array}{l}4 \\
4 \\
4\end{array}$ & $\overline{7}$ & 二 & $\bar{Z}$ & $\bar{z}$ & $\begin{array}{l}2 \\
3 \\
2\end{array}$ & $\begin{array}{l}3 / 17 \\
5 / 20 \\
8 / 19\end{array}$ \\
\hline
\end{tabular}

BW = Body Weight. $n=$ Number of animals.

GSI $=$ Gonosomatic Index $=\frac{\text { gonad weight }}{\text { body weight }} \times 100$. Atr. $=$ Atretic eggs occurring in large numbers. L.Atr. $=$ Large atretic eggs occurring in large numbers.

Same dose, different photoperiods : $\left({ }^{\mathrm{A}}\right)=\mathbf{P}<0.05$., $\left({ }^{\mathrm{B}}\right)=\mathbf{P}<0.02$.

Same photoperiod, different doses : $\left({ }^{a}\right)=\mathbf{P}<0.05$., $\left({ }^{c}\right)=\mathbf{P}<0.01$.

(d). $\left({ }^{d}\right)=P<0.002$, Mann-Whitney U-test.

both males and females under long photoperiod. In experiment 7 there was a marked decline in ovarian activity that was only weakly influenced by the photoperiod. Almost all the ovaries contained large numbers of atretic eggs. High ovarian weights were usually associated with large numbers of large atretic eggs, i.e. probably previously mature eggs in an early stage of atrophy. In experiment 7 the ovarian weights in females injected with the low dose of melatonin under $8 \mathrm{~L}: 16 \mathrm{D}$ were significantly higher than in both the saline-injected and the high dose melatonin-injected group. 
TABLE 3

Effects of melatonin on male reproduction in different seasons and under different photoperiods

\begin{tabular}{|c|c|c|c|c|c|c|c|c|c|c|}
\hline \multirow[t]{2}{*}{ Experiment } & & & \multirow[b]{2}{*}{$\mathrm{n}$} & \multirow[b]{2}{*}{$B W \cdot g \bar{x}$} & \multirow[b]{2}{*}{$G S \mid \bar{x}$} & \multirow[b]{2}{*}{$\mathrm{KEH}, \mu \mathrm{m} \overline{\mathbf{x}}$} & \multirow[b]{2}{*}{$(n)$} & \multicolumn{3}{|c|}{$\begin{array}{c}\text { Spermatogenic class } \\
\text { (frequency) }\end{array}$} \\
\hline & & & & & & & & 1 & 2 & 3 \\
\hline \multirow[t]{3}{*}{1} & \multicolumn{2}{|l|}{ Initial controls } & 11 & 1.11 & 0.83 & 19.1 & & 3 & 4 & 4 \\
\hline & $8 \mathrm{~L}: 16 \mathrm{D}$ & $\begin{array}{l}0 \mu g \\
0.8 \mu g \\
4 \mu g\end{array}$ & $\begin{array}{r}9 \\
9 \\
13\end{array}$ & $\begin{array}{l}1.44 \\
1.23 \\
1.29\end{array}$ & $\begin{array}{l}0.80\left({ }^{B}\right) \\
0.84 \\
0.88\end{array}$ & $\begin{array}{l}15.1\left({ }^{C}\right) \\
14.8\left(^{B}\right) \\
13.8\end{array}$ & $\begin{array}{l}(8) \\
(8)\end{array}$ & $\begin{array}{l}3 \\
2 \\
1\end{array}$ & $\frac{1}{3}$ & $\begin{array}{l}4 \\
5 \\
7\end{array}$ \\
\hline & $16 \mathrm{~L}: 8 \mathrm{D}$ & $\begin{array}{l}0 \mu \mathrm{g} \\
0.8 \mu \mathrm{g} \\
4 \mu \mathrm{g}\end{array}$ & $\begin{array}{r}10 \\
9 \\
3\end{array}$ & $\begin{array}{l}1.31 \\
1.13 \\
1.04\end{array}$ & $\begin{array}{l}0.61\left(^{\mathrm{B}}\right) \\
0.85 \\
0.61\end{array}$ & $\begin{array}{l}24.5\left(^{\mathrm{C}}\right) \\
20.8\left(^{\mathrm{B}}\right) \\
15.8\end{array}$ & & $\begin{array}{l}6 \\
5 \\
3\end{array}$ & $\begin{array}{r}1 \\
1 \\
-\end{array}$ & $\begin{array}{l}3 \\
3 \\
-\end{array}$ \\
\hline \multirow[t]{3}{*}{2} & \multicolumn{2}{|l|}{ Initial controls } & 5 & 1.10 & $0.6 \uparrow$ & 17.3 & & 5 & - & - \\
\hline & $8 \mathrm{~L}: 16 \mathrm{D}$ & $\begin{array}{l}0 \mu g \\
0.8 \mu g \\
4 \mu g\end{array}$ & $\begin{array}{l}8 \\
6 \\
6\end{array}$ & $\begin{array}{l}1.30 \\
1.53\left(^{a}\right) \\
1.01\left(^{a}\right)\end{array}$ & $\begin{array}{l}0.49 \\
0.62 \\
0.55\end{array}$ & $\begin{array}{l}15.9\left({ }^{B}\right) \\
15.8\left({ }^{B}\right) \\
15.6\end{array}$ & (4) & $\begin{array}{l}2 \\
2 \\
1\end{array}$ & $\frac{2}{-}$ & $\begin{array}{l}4 \\
4 \\
5\end{array}$ \\
\hline & $16 \mathrm{~L}: 8 \mathrm{D}$ & $\begin{array}{l}0 \mu g \\
0.8 \mu g \\
4 \mu g\end{array}$ & $\begin{array}{r}11 \\
9 \\
7\end{array}$ & $\begin{array}{l}1.43 \\
1.38 \\
1.12\end{array}$ & $\begin{array}{l}0.62 \\
0.64 \\
0.57\end{array}$ & $\begin{array}{l}22.8\left({ }^{\mathrm{B}}\right) \\
22.9\left(^{\mathrm{B}}\right),\left(^{a}\right) \\
18.2\left(^{\mathrm{a}}\right)\end{array}$ & & $\begin{array}{l}3 \\
4 \\
2\end{array}$ & $\frac{1}{3}$ & $\begin{array}{l}7 \\
5 \\
2\end{array}$ \\
\hline 3 & $15.5 \mathrm{~L}: 8.5 \mathrm{D}$ & $\begin{array}{l}0 \mu \mathrm{g} \\
0.8 \mu \mathrm{g}\end{array}$ & $\begin{array}{l}3 \\
4\end{array}$ & $\begin{array}{l}1.00 \\
1.05\end{array}$ & $\begin{array}{l}0.27 \\
0.49\end{array}$ & $\begin{array}{l}13.3 \\
16.0\end{array}$ & & - & $\overline{1}$ & $\begin{array}{l}3 \\
3\end{array}$ \\
\hline \multirow[t]{2}{*}{4} & \multicolumn{2}{|l|}{ Initial controls } & 6 & 1.07 & 0.36 & 25.2 & & 4 & - & 2 \\
\hline & $15.5 \mathrm{~L}: 8.5 \mathrm{D}$ & $\begin{array}{l}0 \mu \mathrm{g} \\
0.8 \mu \mathrm{g}\end{array}$ & $\begin{array}{l}7 \\
8\end{array}$ & $\begin{array}{l}1.04 \\
1.06\end{array}$ & $\begin{array}{l}0.35 \\
0.34\end{array}$ & $\begin{array}{l}29.0 \\
28.2\end{array}$ & (6) & $\begin{array}{l}7 \\
7\end{array}$ & - & $\overline{1}$ \\
\hline \multirow[t]{3}{*}{5} & Initial controls & & 4 & 1.07 & 0.52 & 32.9 & (3) & 3 & - & - \\
\hline & $8 \mathrm{~L}: 16 \mathrm{D}$ & $\begin{array}{l}0 \mu g \\
0.8 \mu g\end{array}$ & $\begin{array}{l}10 \\
10\end{array}$ & $\begin{array}{l}1.28 \\
1.14\end{array}$ & $\begin{array}{l}0.47 \\
0.55\end{array}$ & $\begin{array}{l}41.4 \\
36.1\end{array}$ & & 9 & $\overline{1}$ & 1 \\
\hline & $16 \mathrm{~L}: 8 \mathrm{D}$ & $\begin{array}{l}0 \mu \mathrm{g} \\
0.8 \mu \mathrm{g}\end{array}$ & $\begin{array}{r}10 \\
9\end{array}$ & $\begin{array}{l}1.25 \\
1.34\end{array}$ & $\begin{array}{l}0.59 \\
0.66\end{array}$ & $\begin{array}{l}42.1 \\
40.0\end{array}$ & & $\begin{array}{l}9 \\
7\end{array}$ & - & 1 \\
\hline 6 & $15.5 \mathrm{~L}: 8.5 \mathrm{D}$ & $\begin{array}{l}0 \mu g \\
0.8 \mu g \\
4 \mu g\end{array}$ & $\begin{array}{l}5 \\
8 \\
5\end{array}$ & $\begin{array}{l}0.67\left(^{a}\right) \\
0.84\left(^{a}\right) \\
0.71\end{array}$ & $\begin{array}{l}0.43\left(^{b}\right) \\
0.37 \\
0.23\left(^{b}\right)\end{array}$ & $\begin{array}{l}19.1 \\
11.8 \\
16.2\end{array}$ & $\begin{array}{l}(7) \\
(3)\end{array}$ & $\frac{2}{1}$ & $\begin{array}{r}1 \\
2 \\
-\end{array}$ & $\begin{array}{l}2 \\
6 \\
4\end{array}$ \\
\hline
\end{tabular}

$\mathrm{BW}=$ Body Weight. GS $=$ Gonosomatic Index $=\frac{\text { gonad weight }}{\text { body weight }} \times 100$.

$\mathrm{KEH}=$ Kidney Epithelium Height. The $n$ for kidney histology is indicated if different from $n$ for weights.

* +1 abnormal specimen

Same dose, different photoperiods : $\left(^{\mathrm{B}}\right)=\mathrm{P}<0.02 .,(\mathrm{C})=\mathrm{P}<0.01$

Same photoperiod, different doses : $\left({ }^{a}\right)=\mathbf{P}<0.05$., $\left({ }^{b}\right)=\mathrm{P}<0.02$

Mann-Whitney U-test.

\section{Discussion.}

Long photoperiods (16L:8D) stimulated reproduction (ovarian maturation and male kidney hypertrophy) in November and January, whereas the sticklebacks matured independently of photoperiod in late spring. These results accord with those obtained by Baggerman $(1957,1972)$. Baggerman (1957) found that the breeding season lasted longer under long photoperiods than under short ones, while in our study the decline of ovarian activity was little affected by light.

All experiments in the present investigation have been performed at a high temperature which, of course, is not the natural one for sticklebacks in winter in Sweden. The high temperature was used as the photoperiodic effects on reproduction in the three- 
spined stickleback are manifested much faster in a high than in a low temperature (Baggerman, 1957, 1972).

It is likely that the combination of short photoperiod and high temperature is the cause of the appearance of atretic eggs in many females in experiments 1 and 2 . Such atretic eggs are absent in the initial controls that had lived under a short photoperiod/ low temperature regime. Undoubtly it was also the high temperature that caused the rapid maturation in both photoperiodic regimes in experiment 5 , considerably in advance of the natural breeding season. The water in the sea was still cold at the beginning of this experiment; ice was still present.

The high dose of melatonin $(4 \mu \mathrm{g} / \mathrm{day})$ had antigonadal effects in experiments 1 and 2 , inhibiting the stimulatory effect of long photoperiods on the kidney and oocyte development. The antigonadal effects in these experiments agree with previous reports on teleosts (Fenwick, 1970 ; Urasaki, 1972 ; de Vlaming, Sage and Chariton, 1974a, b; Sundararaj and Keshavanath, 1976 ; Saxena and Anand, 1977), and are in agreement with the theory of melatonin as a mediator of short-day inhibition of reproduction.

More unexpectedly, progonadal effects of melatonin were also found. A highly significant stimulatory effect on ovarian weights by the low dose of melatonin under $8 \mathrm{~L}: 16 \mathrm{D}$ was found at the end of the breeding season in experiment 7 . When the fish had previously been kept for two or more months under winter conditions (experiments 2,3 and 4$)$, the low dose $(0.8 \mu \mathrm{g} /$ day) increased ovarian weights and stimulated oocyte maturation under long photoperiods. However, these effects were never strong or highly significant. The progonadal effects of melatonin in experiments 2, 3 and 4 do not resemble the stimulatory effect of long photoperiods since only females were stimulated. Also, the effects of melatonin after the end of the breeding season do not resemble either the effects of short or long photoperiods.

Although progonadal effects of melatonin have been found in higher verfebrates (e.g. Turek, Desjardins and Menaker, 1975) in previous studies on lower vertebrates only antigonadal effects (O'Connor, 1969 ; Fenwick, 1970 ; Urasaki, 1972 ; Levey, 1973 ; de Vlaming, Sage and Charlton, 1974a, b ; Sundararaj and Keshavanath, 1976 ; Saxena and Anand, 1977 ; Packard and Packard, 1977 ; Biswas et al., 1978 ; Misra and Thapliyal, 1979 ; Haldar and Thapliyal, 1981) or no effects at all on reproduction (Juszkiewicz and Rakalska, 1965 ; Iwamatsu, 1978) have been found.

Turek, Desjardins and Menaker (1975) implanted melatonin-filled capsules of different lengths $(25,50,100,150,200 \mathrm{~mm})$ in male golden hamsters. Under long photoperiod testes and seminal vesicles were well developed in the control animals and in the $25-\mathrm{mm}$ group, and regressed in the other groups. In short photoperiod reproduction was regressed in the 0 and 200-mm groups, and stimulated in the others. In previous studies on the effects of melatonin in lower vertebrates a stronger inhibitory effect on reproduction by high than low doses have sometimes been found (Sundararaj and Keshavanath, 1976 ; Haldar and Thapliyal, 1981). However, effects of low but not high doses of melatonin on the reproduction of lower vertebrates have not been previously reported.

Tamarkin et al. (1976) found that melatonin injections given late in the day were effective in suppressing reproduction in male and female golden hamsters, whereas injections given in the morning were not. However, de Vlaming, Sage and Charlton 
(1974a) decreased gonadal weights in the teleost Fundulus with melatonin injections both 2 and 8 hrs after lights-on under long-day conditions.

It has been suggested (Reiter, 1976 ; Reiter et al., 1976) that melatonin exerts its gonadal effects by influencing the synthesis/release of antigonadotropic peptides in the pineal organ. This possibility has, so far, not been studied at all among lower vertebrates.

It is not likely that the different results obtained in experiments 6 and 7 are due to the different light intensities used (250 resp. 1300 lux), as Baggerman (1957) found that different light infensities (160-3 230 lux) had at most minor effects on photoperiodic stimulation of reproduction in the stickleback. We think that difference in body size (smaller in experiment 6) is a more likely cause of the discrepancy.

Reçu en décembre 1980. Accepté en mai 1981.

Résumé. Des épinoches (Gasterosteus aculeatus L.) mâles et femelles, tenues dans des régimes photopériodiques différents (LD $8: 16$ ou $16: 8$ heures), ont reçu des injections de mélatonine $(0,8 \mu \mathrm{g}$ ou $4 \mu \mathrm{g}$ par jour) au cours des différentes saisons de l'année. En novembre et janvier, la reproduction a été stimulée par la photopériode longue. Au contraire, la photopériode n'influence que négligemment la maturation sexuelle en mars/ avril ef la régression ovarienne en juillet.

En novembre et janvier, des effets antigonadaux ont été induits par des injections de $4 \mu \mathrm{g}$ de mélatonine par jour. Des injections de $0.8 \mu \mathrm{g}$ de mélatonine par jour ont induit des effets progonadaux en photopériode longue chez des femelles qui avaient été maintenues sous des conditions hivernales pendant quelques mois et chez des femelles sous le régime LD 8 : 16 en juillet.

\section{References}

AMMERMAN F., 1950. A chrome-alum preparation for delicate and difficult fixations. Stain Technol., 25, $197-199$.

BAGGERMAN B., 1957. An experimental study on the timing of breeding and migration in the threespined stickleback (Gasterosteus aculeatus L.). Archs néerl. Zool., 12, 105-317.

BAGGERMAN B., 1972. Photoperiodic responses in the stickleback and their control by a daily rhythm of photosensitivity. Gen. comp. Endocrinol, Suppl. 3, 466-476.

BISWAS N. M., CHAKRABORTY J., CHANDA S., SANYAL S., 1968. A basic experimental approach in perspective of pineal and melatonin involvement in photoperiod-induced alteration of spermatogenesis in toad (Bufo melanosticus). Endokrinologie, 71, 143-148.

BRAEKEVELT C. R., MEMILLAN D. B., 1967. Cyclic changes in the ovary of the brook stickleback Eucalia inconstans (Kirtland). J. Morph., 123, 373-396.

EECKHOUDT J.-P., van den, 1946. Recherches sur l'influence de la lumière sur le cycle sexuel de l'épinoche (Gasterosteus aculeałus). Ann. Soc. r. Zool. Belg., 77, 83-89.

FENWICK J. C., 1970. Demonstration and effect of melatonin in fish. Gen. comp. Endocrinol., 14, 86-97.

GERN W. A., OWENS D. W., RALPH C. L., 1978 . The synthesis of melatonin by the trout retina. J. exp. Zool., 206, 263-270.

GERN W. A., OWENS D. W., RALPH C. L., 1978b. Plasma melatonin in the trout : day-night change demonstrated by radioimmunoassay. Gen. comp. Endocrinol., 34, 453-458.

HAFEEZ M. A., QUAY W. B., 1970. Pineal acetylserotonin methyltransferase activity in the teleost fishes, Hesperoleucas symmetricus and Salmo goirdneri, with evidence for lack of effect of constant light and darkness. Comp. gen. Pharmacol., 1, 257-262. 
HALDAR C., THAPLIYAL J. T., 1981. Effect of melatonin on the testes and the renal sex segments in the garden lizard, Calotes versicolor. Can. J. Zool., 59, 70-74.

IWAMATSU T., 1978. Studies on oocyte maturation of the medaka, Oryzias latipes. VIl. Effects of pinealectomy and melatonin on oocyte maturation. Annotnes. zool. jap., 51, 198-203.

JUSZKIEWICZ T., RAKALSKA Z., 1965. Lack of effect of melatonin on the frog spermatogenic reaction. J. Pharm. Pharmac., 17, 189-190.

LEVEY I. L., 1973. Effects of pinealectomy and melatonin injections at different seasons on ovarian activity in the lizard Anolis carolinensis. J. exp. Zool., 185, 169-174.

MISRA C., THAPLIYAL J. P., 1979. Time of administration of indolamines and testicular response of Indian garden lizard Calotes versicolor. Indian J. exp. Biol., 17, 1383-1385.

O'CONNOR J. M., 1969. Effect of melatonin on in vitro ovulation of frog oocyles. Amer. Zool., 9, 577.

OWMAN C., RÜDEBERG C., 1970. Light, fluorescence, and electron microscopic studies on the pineal organ of the pike, Esox lucius L., with special regard to 5-hydroxytryptamine. Z. Zellforsch. mikrosk. Anat., 107, 522-550.

PACKARD M. J., PACKARD G. C., 1977. Antigonadotrophic effect of melatonin in male lizards (Callisaurus draconoides). Experientia, 33, 1665-1666.

QUAY W. B., 1965. Retinal and pineal hydroxyindole-O-methyltransferase activity in vertebrates. Life Sci., 4, 983-991.

REED B. L., FINNIN B. C., 1973. A unique bioassay for melatonin. Aust. J. pharm. Sci., NS 2, 52-56.

REITER R. J., 1976. Pineal and associated neuroendocrine rhythms. Psychoneuroendocrinology, 1, 255263.

REITER R. J., LUKASZYK A. J., VAUGHAN M. K., BLASK D. E., 1976. New horizons of pineal research. Amer. Zool., 16, 93-101.

SAXENA P. K., ANAND K., 1977. A comparison of ovarian recrudescence in the catfish, Mystus tengara (Ham.), exposed to long photoperiods and to melatonin Gen. comp. Endocrinol., 33, 506511.

SMITH J. R., WEBER L. J., 1976. The regulation of day-night changes in hydroxyindole-O-methyltransferase activity in the pineal gland of the steelhead trout (Salmo gairdneri). Con. J. Zool., 54, 1530-1534.

SUNDARARAJ B. I., KESHAVANATH P., 1976. Effects of melatonin and prolactin treatment on the hypophysial-ovarian system in the catfish, Heteropneusfes fossilis (Bloch). Gen. comp. Endocrinol., 29, 84-96.

TAMARKIN L., WESTROM W. K., HAMILL A. I., GOLDMAN B. D., 1976. Effect of melatonin on the reproductive systems of male and female Syrian hamsters : a diurnal rhythm in sensitivity to melatonin. Endocrinology, 99, 1534-1541.

TUREK F. W., DESJARDINS C., MENAKER M., 1975. Melatonin : antigonadal and progonadal effects in male golden hamsters. Science, 190, 280-282.

URASAKI H., 1972. Effects of restricted photoperiods and melatonin administration on gonadal weights in Japanese killifish. J. Endocr., 55, 619-620.

VEEN TH. van, EKSTRÖM P., BORG B., MØLLER M., 1980. The pineal complex of the three-spined stickleback, Gasterosteus oculeatus L. A light-, electronmicroscopic and fluorescence histochemical investigation. Cell Tiss. Res., 209, 11-28.

VLAMING V. L. de, SAGE M., CHARLTON C. B., 1974a. The effects of melatonin treatment on gonosomatic index in the teleost, Fundulus similis, and the tree frog, Hyla cinerea. Gen. comp. Endocrinol., 22, 433-438.

VLAMING V. L. de, SAGE M., CHARLTON C. B., 1974b. The effects of melatonin on lipid deposition in cyprinodontid fishes and on pituitary prolactin activity in Fundulus similis. J. comp. Physiol., 94, 309-319.

WAI E. H., HOAR W. S., 1963. The secondary sex characters and reproductive behaviour of gonadectomized sticklebacks treated with methyl testosterone. Can. J. Zool., 41, 611-628. 